\title{
Research on the Construction of Teachers Team in Private Applied Colleges and Universities from the Perspective of Independent Evaluation Right
}

\author{
Yuhong Zhan \\ College of Management \\ Wuhan Technology and Business University \\ Wuhan, China \\ 335255299@qq.com
}

\author{
Xiaolin Qi \\ Human Resource Department \\ Wuhan Technology and Business University \\ Wuhan, China \\ 10120217@qq.com
}

\begin{abstract}
This paper is mainly to discuss how private universities utilize the opportunity of delegating the evaluation right to construct applied teachers team. After knowing the current situation of the construction of teachers team in private applied universities on the bas is of the questionnaire and survey and analyzing the influence of the unified evaluation standard for professional title on applied teachers team, the evaluation standard in private applied universities should be modified in which teachers working in enterprises should be regarded as the precondition of professional title evaluation, teaching status should be enhanced and the applicability of research achievements should be emphasized. In addition, the supporting measures should be provided from the aspect of teaching, scientific research and training. The innovation of this paper lies in the influence of policy reform of professional title on private applied universities, which provides suggestions for the construction of applied teachers team in private colleges and universities.
\end{abstract}

Keywords-private applied colleges and universities; independent evaluation right; professional title evaluation; the construction of teachers team

I. THE CURRENT SITUATION OF THE CONSTRUCTION OF APPLIED TEACHERS TEAM IN PRIVATE APPLIED COLLEGES AND UNIVERSITIES

The current situation of the construction of applied teachers team in private applied colleges and universities.

Most private institutions of higher learning in our country have a short history and are inexperienced in running school. In the early stage, they imitated the educational pattern of public institutions of higher learning in an all-round manner. Thus, the talents they cultivated were highly similar with those in public ones. However, inadequate sources in private institutions of higher learning are much less than in public ones, which causes them in a disadvantage position in terms of the quality of talents cultivation when comparing with similar public institutions of higher learning. With the popularization of

This paper is funded by the Key Program of the Ministry of Education in the Twelfth Five-year Plan of the National Office for Education Sciences Planning, that is, Research on the Construction of Performance Evaluation Indicator System for the Classified Management of Application Technology Teachers in Universities (Program No. 2014317), and supported by the Teacher Management Division, Hubei Provincial Department of Education. higher education, the number of institutions of higher learning is soaring, the growth rate of source of students tends to decrease and the competition among institutions of higher learning is getting more and more intense. In order to be more competitive, private institutions of higher learning attempt to transform into applied colleges and universities in accordance with their own characteristics, especially in 2015 when Ministry of Education issued a document to guide part of undergraduate colleges to transform into applied institutions of higher learning. The objective of talent cultivation for private institutions of higher learning is to cultivate applied talents suitable for economic and social development. Only by transforming private institutions of higher learning into applied institutions can the applied teachers team come into being.

With regard to the direction of the construction of applied teachers team, it is widely believed by our scholars that doubleprofessionally-titled teachers should be the focuses for the construction of applied teachers, but at present the consensus has not yet been reached in the identification of teachers with such qualifications. There are various names such as "double certificates", "double quality", "superposition", "double professional titles", "double level" and "specific". Ministry of Education provides suggestions and direction for the construction of applied teachers teams in the appraisal of newly-built undergraduate colleges, holding that doubleprofessionally-titled teachers are those who have both occupational qualifications in industries and teaching experience in colleges.

In 2016, we interviewed 402 teachers in 8 private institutions of higher learning in Hubei province, only to find that $24.1 \%$ teachers are from enterprises. In the same year, we found that from the interview of the persons in charge of human resource in 11 private institutions of higher learning that double-professionally-titled teachers only account for less than $30 \%$ in $54.5 \%$ colleges, $30 \%$ to $40 \%$ in $27.3 \%$ and $40 \%-50 \%$ in $18.2 \%$. Thus, there is a long way to go for the construction of applied teachers team in private institutions of higher learning. 
II. THE INFLUENCE OF UNIFIED PROFESSIONAL TITLE SYSTEM ON THE CONSTRUCTION OF APPLIED TEACHERS TEAM IN PRIVATE INSTITUTIONS OF HIGHER LEARNING

The different development direction of colleges decides the different ability requirement for teachers. Institutions of higher learning with professional title evaluation right often convey their requirements and standard on teachers by formulating professional title evaluation system suitable to their own colleges. Additionally, personal professional development of teachers also orients toward professional title evaluation standard. Therefore, professional title system has far-reaching influence on the construction of teachers team in institutions of higher learning.

Pan Maoyuan (2010) maintains that applied institutions of higher learning should focus on teaching while conducting researches, but the researches they conduct should be applied and developmental researches[1]. However, at present, we attach great importance to research, pay little attention to teaching and ignore the applicability of research achievements in terms of professional titles. Song Guangwen (2010), et al believe that the evaluation of professional titles in institutions of higher learning mismatches teaching and teaching-oriented teachers are paid little attention to under the background of emphasizing research and ignoring teaching, which has negative impact on teaching quality[2]. Han Ming (2010) believes that evaluation system characterized by emphasizing scientific research, paying little attention to teaching and focusing on the quantity of research instead of the quality in institutions of higher learning is the reason for the 'bad money drives out good", which causes those teachers who are highly responsible for teaching to be excluded or even resign[3]. He Rongrong (2012) et al hold that there is no difference between research-based institutions of higher learning and applied one in terms of professional title standard, which both attach great importance to research, thus causing that teaching in applied institutions of higher learning is hard to be identified. But at present, teachers write books on the purpose of professional promotion rather than public causes under the guideline of research. Thus research achievements cannot be used to serve economic development and industries[4]. Zhao Xiangyu (2015) believes that applied teachers from industries and enterprises have advantages in teaching but disadvantages in research. And "scientific research" is the key for teachers in institutions of higher learning to get promotion. Such unscientific evaluation system will influence the educational quality of private applied universities[5]. Zhao Ling (2016) maintains that applied colleges and universities do not differ from traditional undergraduate ones in terms of the importance of practice and research achievements[6]. Zhao Tianying (2018) believes that applied institutions of higher learning should be distinct from traditional ones, but existing professional title evaluation system does not reflect the characteristics of applied teachers[7].

In conclusion, it is found that unified professional title standard formulated by educational administrative department orients toward academic aspect instead of non-teaching and applied aspects. Furthermore, relatively unified evaluation standard does not take different requirements on teachers' ability in colleges with different types and levels into consideration. Therefore, existing professional title evaluation standard cannot meet the need of applied teachers team for private applied colleges and universities.

III. SEIZING THE OPPORTUNITY OF DELEGATING THE PROFESSIONAL TITLE EVALUATION RIGHT AND GIVING PLAY TO THE GUIDING ROLE OF PROFESSIONAL TITLE SYSTEM IN THE CONSTRUCTION OF APPLIED TEACHERS

The key to the successful transformation into applied colleges and universities for private institutions of higher learning is to transform into an applied teachers team. Therefore, the objective for private applied institutions of higher learning is to build a well-constructed, high quality and applied teachers team. The past orientation of professional title made the private institutions of higher learning in the midst of transformation but the construction of teachers team had not corresponding changes and was still in accordance with the standard of undergraduate institutions of higher learning. The number of students decided that of teachers. Teachers with high degree and senior professional titles were paid much attention to whereas the proportion of applied teachers and the promotion of teachers' applied ability were ignored.

In 2017, Hubei province delegated the evaluation right of professional title in institutions of higher learning for all undergraduate colleges and universities in the whole province. Each institution of higher learning can formulate evaluation standard independently, but the standard should meet the basic requirement of the one formulated in 2013. Therefore, private applied institutions of higher learning can use the opportunity of delegating evaluation right to give full play to the guiding role of professional title system for the construction of teachers team. And on the basis of meeting the basic requirements of the province and in accordance with self-development, it should formulate individualized evaluation standard and emphasize teachers' applied ability and achievements. The author believes that private institutions of higher learning can adjust from the following aspects:

\section{A. That teachers work in enterprises should be the precondition of professional title evaluation}

Applied colleges and universities require teachers to master solid and advanced theoretical knowledge as well as practical knowledge. At present, our teachers mainly come from institutions of higher learning. What they receive in colleges is academic education. Thus they are relatively weak in practical knowledge and ability. These innate reasons make teachers impart theoretical knowledge in classrooms for most of time, which violates the principle of putting equal importance of theory and practice in applied colleges. Acquired reasons are that colleges does not regard teachers' practical ability as the evaluation condition in the professional title evaluation, which makes teachers unwilling to actively improve practical ability, even that they know there is a gap between their own abilities and applied teachers' abilities. Therefore, in evaluation for professional title, the author suggests that teachers should work in enterprises which can be considered as precondition, thus guiding teachers to keep in close touch with enterprises in talents cultivation, get to know actual needs of industries and enterprises, and adjust the plan of talents cultivation and courses contents in accordance with the need of enterprises. It 
should be diversified in the evaluation for the experience of teachers' working in enterprises, including full-time practice in enterprises, investigation of typical enterprises by using spare time in order to know work procedures of enterprises and the requirement of jobs, investigation report, etc.

\section{B. Improving the status of teaching in the evaluation of professional title}

Although the past condition for professional title evaluation regarded teaching load and teaching effect as the basic conditions, it had unclear requirement for teaching. As a result, teaching in professional title evaluation is a soft indicator, while scientific research is a hard indicator and an overwhelming indicator. In the practice of professional title evaluation, teaching load can be ignored only if teachers are good at research and teaching. Thus, the status of teaching is less important than research. The orientation of professional title evaluation makes teachers focus on research and neglect teaching in terms of their own development. At present, private applied colleges and universities in our country mainly cultivate undergraduates, thus it should focus on teaching and take teaching quality as a key factor to develop colleges. It must improve the status of teaching in professional title evaluation, regard teaching as the hard indicator and increase the importance of teaching in the evaluation so that teachers can be guided to attach importance to teaching. In the evaluation, it should focus on teaching load as well as teaching effect.

\section{Emphasizing the applicability of achievements in performance}

It is controversial whether private applied colleges and universities should have requirements on teachers' scientific research. Some scholars believe that research can be neglected as long as teaching effect are outstanding. Some scholars believe that teaching and research are of equal importance and cannot be replaced by each other. The author believes that research achievements have been widely recognized as an important indicator of a college's strength and it is not in line with the requirements of colleges and basic requirements of the province not to assess teachers' research achievements. Therefore, it is better for private institutions of higher learning to evaluate teachers' academic performance. However, when evaluating academic performance, it should highlight the practicability of research achievements including the promoting role of teaching achievements in teaching or the contribution of research achievements on industries and society rather than focusing on theoretical innovation of academic achievements just like academic-oriented colleges and universities. By setting the standard of professional title evaluation, the applicability of teaching achievements can be stressed and researches taking roots in actual requirement and serving society in private applied colleges and universities can be highlighted, which are consistent with the orientation of public applied colleges and universities.
IV. SUPPORTING MEASURES FOR THE CONSTRUCTION OF TEACHERS TEAM IN PRIVATE INSTITUTIONS OF HIGHER LEARNING UNDER THE GUIDANCE OF PROFESSIONAL TITLES

As a matter of fact, by adjusting the standard of professional title, private applied colleges and universities can guide teachers to improve their abilities in the light of the change of orientation of colleges to get promoted in professional titles. But such change not only relates to the effort of teachers, but also to colleges' environment. Therefore, it must have corresponding supporting measures to give play to the guiding role of the system of professional title in applied teachers. The main measures are as follows:

\section{A. Stressing teaching and supporting teaching reform}

Applied colleges and universities focus on teaching, which aims to cultivate students to be able to correctly use theoretical knowledge to solve actual problems and meet the need of enterprises and society. Therefore, theoretical teaching and practical teaching in applied colleges are of equal importance and it should change such behavior of emphasizing theory and neglecting practice. In the aspect of teaching, it should also change traditional teacher-centered teaching method, adopt student-centered teaching method and lay emphasis on interactive and heuristic teaching method. Teaching contents and methods of teachers have close relationship with the support of colleges. Colleges should encourage teachers to reform teaching and provide psychological and resources support for the reform. Due to lack of experience, the teaching reform can be carried out on a pilot basis. In teaching reform, administrators should understand that every reform is risky, having the possibility of success and failure. In strengthening teaching supervision, we should be willing to tolerate failure and solve problems in teaching reform with teachers rather than calling to account.

\section{B. Creating platforms and encouraging the transformation of research achievements}

The teaching-centered mode in applied institutions of higher learning does not represent that teachers are not encouraged to research. It just stresses the applicability of research achievements of teachers, no matter it is the achievements of teaching research or scientific research. To promote the applied transformation of research achievements of teachers, it not only requires colleges to provide the platform of teaching reform, encourage teachers to apply their achievements of teaching research into teaching and realize the improvement of teaching through research, but also need to emphasize on the applicability of research achievements in order to serve industries and society and accord with the direction of applied colleges and universities serving the local economic and society.

The cooperation between colleges and enterprises is an important attempt for applied colleges and universities to cultivate applied talents and has made significant achievements. But at present, such cooperation focuses on the cooperation between students, colleges and enterprises. Teachers take few parts in the cooperation and do not realize the integration of production, study and research. In fact, the cooperation can be further strengthened. Colleges can encourage teachers to participate in such cooperation, for example, it can encourage 
teachers to develop new technologies and invents by researching cooperative enterprises or orienting towards the needs of enterprises, which can make research achievements directly serve enterprises. Wuhan Technology and Business University makes an attempt in the aspect of transformation of research achievements, encouraging teachers who works in enterprises to sign horizontal project with enterprises which will closely connect researches of teachers with the needs of enterprises.

\section{Emphasizing on-the-job training of teachers and promoting their professional development}

It is found by investigation in 2016 that private institutions of higher learning make few efforts in teachers' training and teachers receive little on-the-job training. Applied institutions of higher learning need applied teachers. And at present, most teachers are from institutions of higher learning and the education they receive is traditional research-based education. Through on-the-job training, it can, on the one hand, change such inertial understanding as "emphasizes theories and neglects"; on the other hand, it can improve teachers' practical ability. Private applied colleges and universities should realize that it is unpractical only by introducing applied teachers from outside and it should cultivate their own applied teachers team.

In terms of knowledge input and output, teaching itself is the process of knowledge output. And it outputs advanced and correct knowledge. However, nowadays, the speed to update knowledge and technologies is very fast. Teachers should update their own knowledge; otherwise what they impart cannot meet the need of enterprises on talents. And on-the-job training provides critical support for the output of new theories and skills. Therefore, private applied colleges and universities should invest more in training teachers, encourage them to take part in on-the-job training including emerging teaching philosophies and methods in order to know the latest teaching philosophies and methods and to participate in conference of the industry to know the latest knowledge of this industry.

\section{CONCLUSION}

The construction of applied teachers team is the key for private institutions of higher learning to transform into applied one. And the standard of professional title evaluation plays a guiding role in the construction of teachers team. Therefore, private institutions of higher learning should make full use of independent evaluation right of professional title in the construction of applied teachers team and formulate individualized evaluation standard to meet the requirement of applied colleges and universities on teachers team while meeting the basic requirements of professional title issued by Ministry of Education. In the aspect of the conditions of professional title evaluation, it should emphasize both the important status of teaching, particularly practical teaching and the quantity and quality of researches. But in the aspect of the evaluation on research achievements, it should stress its applied characteristics. Private applied colleges should realize that it is not enough to adjust evaluation standard and it should have supporting measures, including supporting teaching reform, deepening the cooperation between production, study and research, encouraging the transformation of research achievements and paying high attention to the on-the-job training of teachers.

\section{REFERENCES}

[1] Pan Maoyuan, What is Applied Undergraduate?[J]. Higher Education Exploration, 2010(1):10-11 (In Chinese)

[2] Song Guangwen, Li Jianhui, He Wenguang, Reflection on the Reform of Professional Title for Teachers in Institutions of Higher Learning[J]. Journal of National Academy of Education Admin istration, 2010(5):2025 (In Chinese)

[3] Han Ming, On Causes and Suggestion for the Phenomenon of "Bad Money Drives Out Good" in Institutions of Higher Learning from the Perspective of Professional Evaluation Title[J]. Higher Education Exploration, 2010(3):133-135 (In Chinese)

[4] He Rongrong, He Jiming, On Disadvantages of Putting Equal Importance on Teaching and Research in Applied Institutions of Higher Learning[J]. Education and Vocation, 2012(36):25-27 (In Chinese)

[5] Zhao Xiangyu, Xiang Chaochun, Analysis on the System for the Construction of Applied Teachers Team in Local Institutions of Higher Learning[J]. Education and Vocation, 2015(19):57-59 (In Chinese)

[6] Zhao Ling, Analysis on the Management of Elaborated Classification of Teachers Team in Applied Universities[J]. Engineering Technology: Full Text Version, 2016(11):00090-00090 (In Chinese)

[7] Zhao Tianying, Opportunities and Challenges for Private Institutions of Higher Learning to Take Over the Evaluation Right of Professional Title--A Case Study of Nanning University[J].Chinese Market, 2018(11) (In Chinese) 